\title{
Rafał Górski, Polscy zamachowcy. Droga do wolności, Wydaw- nictwo „Egis Libron”, Kraków 2008, ss. 384.
}

Wydana w 2008 roku przez Wydawnictwo „Egis Libron” książka pt. „Polscy zamachowcy. Droga do wolności” jest ostatnią publikacją książkową Rafała Górskiego - przedwcześnie zmarłego naukowca, publicysty i działacza społecznego ${ }^{1}$.

Lektura Polskich zamachowców... przekonuje, że celem Autora pracy była rzetelna historycznie, a zarazem dynamiczna i barwna (adekwatnie do przedmiotu), prezentacja działań polskich zamachowców, motywowanych walką z osobami lub grupami personifikującymi państwa zaborcze lub okupacyjne ${ }^{2}$. Przedmiotem opracowania są wyłącznie zamachy dokonywane przez polskich bojowników wymierzone w przedstawicieli instytucji tychże państw. Pozycję tę zalicza się do gatunku zbeletryzowanej historii - co z naukowej perspektywy należy uznać za czynnik niekorzystny. Jednak dzięki rozbudowanej płaszczyźnie formalnej, a także dodającej dramatyzmu i dodatkowo pobudzającej emocje sensacyjnej narracji, zawiera więcej treści, niż „suche” fakty, wymieniane standardowo w większości dotychczasowych opracowań historycznych³. Książce Górskiego z pewnością nie można odmówić wartości naukowej. Rzetelność podawanych faktów nie budzi wątpliwości. Autor przedstawił poszczególne akty przemocy

1 Rafał Górski (ur. 22 września 1973 r. w Krakowie, zm. 4 lipca 2010 r. w Krakowie). Doktor nauk humanistycznych w zakresie historii. Pracownik Wydziału Nauk Społecznych Uniwersytetu Śląskiego. Brał udział w wielu krajowych i międzynarodowych konferencjach naukowych. Opublikował kilkanaście artykułów naukowych omawiających dwudziestowieczną historię Bliskiego Wschodu i monografię pt. Terroryzm ugrupowań fundamentalistycznych (na obszarze Izraela w II połowie XX wieku). Ponadto publikował na łamach prasy anarchistycznej i robotniczej m.in. w: „Innym Świecie”, „Mać Pariadce”, „Przeglądzie Anarchistycznym”, „Recyklingu Idei” i „Trybunie Robotniczej”. W latach 2000-2004 współredagował pismo anarchistyczne „A-tak”. W swoich tekstach zajmował się głównie teorią i praktyką demokracji uczestniczącej, a także historią anarchizmu i syndykalizmu na ziemiach polskich, oraz popularyzowaniem idei spółdzielczości. Był animatorem ruchu anarchistycznego, syndykalistycznego i ekologicznego, a także działaczem niepodległościowym, samorządowym, związkowym i aktywistą ruchu obrony praw lokatorskich.

2 Zarządzenie Komendy Głównej AK z 13 marca 1943 r., stawiając dywersję i sabotaż na pierwszym miejscu wśród najważniejszych kierunków działalności bojowej, w punkcie trzecim głosiło: „Terror w stosunku do Niemców, volksdeutschów i wszystkich współpracujących z okupantem [...]”. Cyt. za: R. Górski, Polscy zamachowcy. Droga do wolności, Kraków 2008, okł. s. 4.

3 W odróżnieniu od beletrystyki sensu stricto literatura faktu (do której to kategorii należy zakwalifikować omawianą pozycję) nie posługuje się fikcją w przedstawianiu opisywanej rzeczywistości, ale jej celem jest rzetelna relacja autentycznych wydarzeń. Por.: S. Król, Cytadela warszawska, Warszawa 1978; L. Pastusiak, Zamachy na prezydentów USA, Warszawa 2010; W. Pawlak, Z księgi zamachów, Warszawa 1985; C. Withing, Rozkaz: zabić Eisenhowera. Zamachy na Hitlera, Churchilla, Stalina, Himmlera i innych przywódców..., Warszawa 2006.

4 Zob.: H. White, Poetyka pisarstwa historycznego, Kraków 2000; idem, Proza Historyczna, Kraków 2009. 
w oparciu o materiały źródłowe, szczegółowo analizując przebieg poszczególnych zamachów. Jednocześnie adekwatnie i wyraziście opisał ich kontekst społeczno-polityczny. Drobiazgowo przedstawił wszystkie sekwencje i następujące po sobie wydarzenia (łącznie z losami zamachowców po dokonaniu dzieła), syntezując ich przyczynowo-skutkowe relacje.

Publikacja Polscy zamachowcy... podzielona jest na dziewiętnaście rozdziałów. Każdy z nich przedstawia inny akt przemocy, a zakres chronologiczny stanowią lata: 1862 (zamach na wielkiego księcia Konstantego Nikołajewicza) i 1945 (zamach na niemieckich żołnierzy stacjonujących na zamku w Nowym Sączu). W przedziale zakreślonym tymi datami znajdujemy opisy zamachów na: Władimira Afanasjewa, Teodora Berga, Nikołaja Kazankowa, Wilhelma Koppe, Nikołaja Dawidowia Seliwerstowa, Georgija Antoniewicza Skałona, Ericha Schulze i kilka innych osób. Ponadto oprócz jednostkowych aktów przemocy Autor opisał masowe zamachy jak: na kawiarnię „Cyganeria” czy wybuch na dworcu S-Bahnhof Friedrichstrasse (rozdz. XIV i XVI). Niektóre z zamachów były udane, inne kończyły się niepowodzeniem, a wśród jednych i drugich zdarzały się również takie, w których były przypadkowe ofiary.

Za szczególnie ciekawe informacje zawarte w omawianej pozycji, dotyczące zamachów, których szczegóły nie były dotychczas powszechnie znane, można uznać fragment o zamachu z użyciem broni biologicznej, przeprowadzonym przez Mariana Bombę (rozdz. XV); a także opis akcji skrajnie radykalnej grupy „Rewolucjonistów-Mścicieli”, którzy określali się mianem „terrorystów ekonomiczno-politycznych”, a swój cel definiowali jako „walkę o wyzwolenie klasy robotniczej spod jarzma burżuazyjno-rządowego" (rozdz. XII) ${ }^{5}$. Ponadto Autor interesująco wyeksponował zamachy dokonane z udziałem kobiet (rozdz.: IX i XI), wskazując fakt zróżnicowania ich pochodzenia społecznego. Nieszablonowa jest również relacja z wydarzeń toczących się wokół kwestii strajku szkolnego lubelskich gimnazjalistów (rozdz. VII).

Wszystkie opisy zamachów mają podobną budowę strukturalną. Na wstępie Autor, w dynamicznym zarysie, przedstawia sytuację na kilka chwil przed zdarzeniem albo krótki opis samego aktu przemocy, a następnie prezentuje rozbudowaną charakterystykę zamachowca, etap przygotowań do zamachu, fazę jego przeprowadzenia, a na zakończenie skutki i dalsze konsekwencje przeprowadzonego aktu przemocy. Dostosowany do opisu poszczególnych okresów język jest właściwy dla epoki, a jednocześnie błyskotliwy. Wskazane walory sprawiają, że książkę czyta się dobrze, a płynna narracja i niewystępowanie powtórzeń terminologicznych w opisach kolejnych zamachów, zachęcają do kontynuowania lektury po każdym kolejnym epizodzie.

5 E. Ajnenkiel, Rewolucyjni Mściciele, „Rocznik Lódzki”, t. XXIX, 1980, s. 183-184. 
Warte odnotowania jest to, że w swojej pracy R. Górski dostrzegł i zaakcentował fakt, iż dla działań wielu polskich zamachowców nadrzędną kwestią była walka z zaborcą lub okupantem, bez względu na jej konsekwencje dla innych narodów, czy społeczności międzynarodowej. Szczególnie widoczne jest to w odniesieniu do zamachu Ignacego Hryniewieckiego (rodem pochodzącego z Podlasia) na cara Aleksandra II, który to zamach miał miejsce w Sankt Petersburgu, w dniu 13 marca 1881 roku. Wówczas Hryniewiecki (ps. „Kociak”) rzucił bombę w powóz cara Aleksandra II, od której ostatecznie zginął zarówno car, jak i sam zamachowiec (rozdz. IV). Śmierć Aleksandra II zniweczyła plany cara zmierzające do wprowadzenia w Rosji nowoczesnego państwa konstytucyjnego z bardzo ograniczonym, ale jednak wymiernym udziałem społeczeństwa we władzy, co miało przemienić poddanych monarchy w obywateli. Tron carski po Aleksandrze II przejął jego syn Aleksander III, który kontynuował politykę despotyzmu, cofając wszystkie demokratyczne reformy swojego ojca ${ }^{6}$.

Autor zbadał i ukazał w Polskich zamachowcach... ten aspekt polskiej historii - akty przemocy dokonywane przez Polaków w walce z jarzmem narodowościowym i społecznym, który dla części narodu jest bohaterstwem i chwalebnym powodem do dumy, dla innej zaś przyczyną hańby i źródłem wstydu. Opisane przez R. Górskiego zamachy stanowiły reakcję na terror państw zaborczych lub okupacyjnych i były zabójstwami osób, które stanowiły symbol ucisku i bezprawia ze strony tychże państw, ale jednak nie następowały one raczej w ramach działań zbrojnych. Jeśli nawet zamach na SS-brigadeführera Franza Kutscherę (rozdz. XVII), zwanego przez Polaków „katem Warszawy”, można jeszcze uznać za odwetowe działanie zbrojne organizacji ruchu oporu ${ }^{7}$, to już w żaden sposób nie mieści się $\mathrm{w}$ tej kategorii próba wysadzenia przez polskich konspiratorów prawosławnej cerkwi Wniebowzięcia Najświętszej Marii Panny ${ }^{8}$, przy ul. Miodowej w Warszawie (rozdz. VI), wypełnionej zarówno carskimi oficerami jak i zwykłymi warszawiakami, która to akcja byłaby niewątpliwie aktem przemocy mogącym zakończyć się śmiercią setek cywilów (jednym z współautorów tego zamachu i konstruktorem ładunku wybuchowego, który miał pozbawić życia generała-gubernatora Josifa Romejko-Hurko i innych przedstawicieli rosyjskiej elity wojskowej mających zginąć wraz z nim, był Ignacy Mościcki, późniejszy prezydent suwerennej Polski ${ }^{9}$ ). Zamach ten ostatecznie nie został przeprowadzony, ponieważ o przygotowaniach do niego dowiedziały się władze carskie. Współcześnie postawy i zachowania tego rodzaju definiuje się jednoznacznie

\footnotetext{
6 Zob. E. Radziński, Aleksander II. Ostatni Wielki Car, Warszawa 2005.

7 Zob.: M. Dunin-Wąsowicz, Zamach na Kutschere, Warszawa 1957; P. Stachniewicz, Akcja Kutschera, Warszawa 1982.

8 Obecnie kościół Bazylianów [przyp. E. Sz.].

9 Zob. A. Chojnowski, P. Wróbel, Prezydenci i premierzy Drugiej Rzeczpospolitej, Wrocław-Warszawa-Kraków 1992.
} 
jako terroryzm i określa się je pejoratywnymi terminami mającymi zdecydowanie negatywną wymowę ${ }^{10}$.

Zaznaczyć należy, iż Autor opisywanych wydarzeń nie stara się być ani oskarżycielem, ani adwokatem, ani też sędzią zamachowców. Nie ocenia w kategoriach etycznych, ani ich działań, ani motywów ${ }^{11}$. Jedynie kronikarsko relacjonuje przebieg poszczególnych aktów przemocy oraz ciąg zdarzeń, które do nich prowadziły, a następnie opisuje skutki zamachów. Przyjmuje, że w tym przypadku osoby zamachowców traktować należy jako bojowników o niepodległość. Jednakże z uwagi na przyjętą przez Autora optykę omawianą pozycję należy uznać za odważną i nowatorską w polskiej literaturze faktu.

$\mathrm{Z}$ uwagi na to, że Polscy zamachowcy... to publikacja należąca do kategorii literatury faktu, braku występowania w jej strukturze standardowego aparatu naukowego nie należy postrzegać jako jej wady. Nieobecność odsyłaczy oraz nie do końca zgodna z metodologią konstrukcja bibliografii, nie pozbawiają książki wartości naukowej, a jedynie nadają jej charakter publikacji popularno-naukowej. Pracy R. Górskiego z pewnością nie można zarzucić, ani niedostatków w zakresie przygotowania naukowego, ani nierzetelności podawanych faktów, ani też niedociągnięć w historycznej narracji. Omawiane opracowanie ocenić należy pozytywnie i uznać za ze wszech miar godne polecenia.

Dodatkową zaletą publikacji jest obfitość ilustrującego ją materiału ikonograficznego. Starannie wyselekcjonowane fotografie ukazują postaci zamachowców, a zdjęcia i rysunki broni oraz schematów sytuacyjnych, znakomicie dopełniają opisy poszczególnych aktów przemocy. Jednocześnie stanowi to niewątpliwie zachętę po sięgnięcie do tej książki dla mniej wymagającego czytelnika, a tym samym przyczynia się do popularyzacji zagadnień będących przedmiotem opracowania, co należy uznać za walor edukacyjny książki.

10 Zob. A. Berko, Droga do raju. Świat wewnętrzny zamachowców samobójców, Warszawa 2010.

11 O motywacjach (zarówno uświadamianych i trwale obecnych w kulturze społeczeństw, jak i nie uświadamianych, ale zakorzenionych w podświadomości jednostek) sprawców aktów przemocy interesująco pisał słoweński filozof Slavoj Žižek. Według Žižka przemoc jest konstytutywnym składnikiem każdego społeczeństwa i chociaż przemoc obecna jest wszędzie, ludzie nie potrafią jej dostatecznie wytłumaczyć, ani zaakceptować. Žižek sformułował tezę, że przemoc widoczna, której ludzie są naocznymi świadkami, ma swe źródło w przemocy ukrytej, stanowiącej podstawę działania systemów politycznych i ekonomicznych. Widzialna przemoc zbrodniarzy czy terrorystów często wydaje się zakłócać normalny (spokojny), stan rzeczy, jednak u podłoża tej normalności leży przemoc ukryta. Według Žižka przemoc jest integralną częścią każdego systemu, na którym opiera się społeczeństwo. Chociaż wydaje się nieprzejrzysta, to stanowi klucz do lepszego zrozumienia tego, co w ludzkiej codziennej praktyce uznaje się często za irracjonalne wybuchy agresji (Žižek w swoim studium przemocy badał zbrodnicze reżimy totalitarne XX w., ale także dokonał bezwzględnej wiwisekcji współczesnych demokracji, podległych regułom ekonomii). Zob. S. Žižek, O przemocy, Warszawa 2010. Por. E. Fromm, Anatomia ludzkiej destrukcyjności, Poznań 1999; idem, Ucieczka od wolności, Warszawa 1999. 
W czasach tzw. wojny z terroryzmem, obecnej zarówno we współczesnym polskim życiu społecznym (głównie w postaci lęków ksenofobicznych i będącej ich emanacją agresji), jak i w retoryce polskich elit politycznych, warto pamiętać, że również polscy bojownicy w okresie rozbiorów (a także później w czasach II Rzeczypospolitej oraz pod okupacją z okresu II wojny światowej, jak również we wczesnej fazie powstawania i umacniania się Polski Ludowej12) korzystali z tego typu metod walki wyzwoleńczej i politycznej. Dokonywali oni zamachów w formie zarówno indywidualnych egzekucji, jak i zbiorowych aktów przemocy. Skutkiem aktywności bojowników nierzadko były wydarzenia dramatyczne i brzemienne w następstwach, ponieważ powodowały i generowały napięcia społeczne, ale taki właśnie stan rzeczy był zgodny z celami przyświecającymi zamachowcom. Historię tych zdarzeń oraz ich kontekst społeczno-polityczny przypomniał w swojej książce R. Górski, który w interesujący i przystępny sposób przedstawił szereg zamachów z XIX i pierwszej połowy XX wieku, dokonanych przez polskich zamachowców w drodze do wolności.

Ernest Szum

Biała Podlaska

\section{Anarquistas de Bialystok, Edicions Anomia/Furia Apátrida, Mayo 2009, Barcelona \& Manresa; 1-a Edición, 216 ss.}

Tą pionierską publikacją poświęconą białostockim początkom polskiego (oraz prawdę mówiąc, rosyjskiego) ruchu anarchistycznego znane katalońskie oficyny libertarne zawstydziły niewątpliwie polskich badaczy tej problematyki, zwłaszcza białostockich. To nic, że nie jest to z pewnością pełna i rzetelna naukowo monografia tematu zasygnalizowanego w tytule. Znów daliśmy się ubiec, mimo wyraźnego w ostatnich latach ożywienia rodzimych badań nad dziejami anarchizmu na ziemiach polskich, które zaowocowało m.in. pierwszymi poważnymi studiami poświęconymi postaciom, takim jak Augustyn Wróblewski czy Józef Zieliński, opracowaniami dotyczącymi syndykalizmu lat międzywojennych, przygotowywanymi do druku wiwisekcjami pogromów na ziemiach polskich oraz pierwszymi specjalistycznymi konferencjami naukowymi.

$\mathrm{Na}$ barcelońskie wydawnictwo, o powodzeniu którego świadczy dobitnie druga edycja zapowiedziana na rok 2012, składają się elementy mocno zróżnicowane pod względem zawartości informacyjnej. Mamy tu więc, przede wszystkim spisane na gorąco w Paryżu w r. 1909 i opublikowane przez „Iwana Musila”, czyli Nikołaja Rogdajewa (zwanego „wujaszkiem Wanią” rosyjskiego anar-

12 Zob. A. Zechenter, Elektryk, który chciał zabić Gomułkę, „Dziennik Polski”, 13 lipca 2009 r. 